\title{
Tatlı Mısırın Kalite Kriterlerine Göre Optimum Hasat Zamanının Belirlenmesi
}

\author{
Doğukan KANTARCI ${ }^{1} \quad$ Fikret PAZIR ${ }^{1} \quad$ Deniz IŞTiPLILER ${ }^{2}$ *Muzaffer TOSUN² \\ Fatma AYKUT TONK²
}

\author{
${ }^{1}$ Ege Üniversitesi, Mühendislik Fakültesi, Gıda Mühendisliği Bölümü, İzmir \\ ${ }^{2}$ Ege Üniversitesi, Ziraat Fakültesi, Tarla Bitkileri Bölümü, İzmir \\ *Sorumlu yazar e-posta (Corresponding author; e-mail): muzaffer.tosun@ege.edu.tr
}

\section{Öz}

Bu çalışmada, üç farklı zamanda (6 Mayıs, 20 Temmuz ve 20 Ağustos) ekilen, üç farklı tatı mısır çeşidinin (Sunshine, El toro ve Merkür) üç farklı dönemde (süt olum, sarı olum ve hamur olum) hasat edilmesi sonucu elde edilen tatlı mısırların kalite kriterlerinin belirlenmesi ve bu kriterlere göre optimum hasat zamanının saptanması üzerine çalışı ımıştır. Her ekim zamanında, her çeşitten üç farklı hasat döneminde mısır örnekleri hasat edilmiş ve tanelenmiştir. Tane boyut ölçümü, 1000 tane ağırlığı, toplam kuru madde, nişasta, suda çözünür kuru madde, şeker, tekstür, renk değerleri $\left(L^{*}, a^{*}, b^{*}\right)$, protein ve duyusal analizleri yapılmıştır. Araştırma sonucunda, hasat dönemleri geciktikçe tane boyutları, 1000 tane ağırlığı, toplam kuru madde, nişasta, tekstür, $L^{*}, a^{*}, b^{*}$, protein değerleri artmış ve suda çözünür kuru madde, şeker değerleri azalmıştır. İnvert şeker, toplam şeker, nişasta ve duyusal analizlerden lezzet özelliklerine göre optimum hasat dönemleri Sunshine çeşidi için Mayıs ekim zamanında süt olum hasat dönemi için (ekimden hasada kadar geçen süre ) 83 gün, Temmuz ekim için süre 72 gün ve Ağustos ekimi için 89 gün olarak belirlenmiştir. Merkür çeşidi için Mayıs ekim zamanında süt olum hasat dönemi (ekimden hasada kadar geçen süre) için 87 gün, Temmuz için 77 gün ve Ağustos ekimi için 107 gün olarak belirlenmiştir. El toro çeşidi için ise optimum hasat dönemleri Mayıs ekim zamanında süt olum hasat dönemi (ekimden hasada kadar geçen süre) için 89 gün, Temmuz ekimi için 79 gün ve Ağustos ekimi için 100 gün olarak belirlenmiştir.

Anahtar Kelimeler: Tatı mısır, ekim zamanı, hasat zamanı, şeker içeriği

\section{Optimization of Harvesting Time by Quality Criteria of Sweet Corn}

\begin{abstract}
In this study, the quality criteria which are important for food processes of three different types of sweet corn (such as Sunshine, El toro and Merkür) was investigated and harvesting periods were optimized sweet corn varieties have been planted in three different planting times (such as May $6^{\text {th }}$, July $20^{\text {th }}$ and August $20^{\text {th }}$ ) and harvested in three different harvesting periods (such as milk stage, yellow stage and dough stage). Sweet corns were planted in Bornova region located in Izmir on 2011. Sweet corn samples harvested and striped the kernels from an ear of sweet corn for every planting time for each type of sweet corn and in each harvesting periods. There was a difference between each harvesting period which belongs to types of sweet corn and planting times approximately 7 days. Analyses of size of sweet corn piece measurement, weight of thousand pieces of sweet corn, total dry matter content, starch content, soluble dry matter content, sugar content, protein contenti texture, color and sensory analysis were conducted in sweet corn pieces. In conclusion, when quality properties of sweet corn especially invert sugar content, total sugar content, starch content and sensory analysis based on taste results considered, for Sunshine optimum harvesting periods were selected as milk stage of May $6^{\text {th }}$ planting time (time to planting to harvest 83 days), milk stage of July $20^{\text {th }}$ planting time (time to planting to harvest 72 days) and milk stage of August $20^{\text {th }}$ planting time (time to planting to harvest 89 days). According to the same properties, optimum harvesting periods for Merkür were selected as milk stage of May $6^{\text {th }}$ planting time (time to planting to harvest 87 days), milk stage of July $20^{\text {th }}$ planting time (time to planting to harvest 77 days) and dough stage of August $20^{\text {th }}$ planting time (time to planting to harvest 107 days). However, optimum harvesting periods for El toro were selected as milk stage of May $6^{\text {th }}$ planting time (time to planting to harvest 89 days), milk stage of July $20^{\text {th }}$ planting time (time to planting to harvest 79 days) and yellow stage of August $20^{\text {th }}$ planting time (time to planting to harvest 100 days).
\end{abstract}

Keywords: Sweet corn (sugar corn), planting time, harvesting period, quality properties 


\section{Giriş}

Ü Ikemizde, son yıllarda işlenmiş mısır ürünleri tüketimi arttığı halde, şeker mısırı yeterince tanınmadığından üretiminde önemli çıkışlar gözlenmemektedir (Atakul 2011). Diğer bir ifadeyle, şeker mısırı yetiştiriciliği ülkemizde, dar bir alanda ve az sayıda çeşitle yapılmaktadır. Türkiye'de gıda sanayi gereksinimini karşılamak için çiftçilere sözleşmeli şeker mısırı ekimi yaptırmaktadır (Eşiyok ve ark., 2011). Ekimi yaptırılan çeşitlerin çoğunluğunu eski çeşitler oluşturmaktadır. Bu çeşitlerin kalite özellikleri yeni çeşitlere kıyasla oldukça düşüktür. Bu nedenle de, sanayi kuruluşları genellikle istedikleri niteliklere sahip ürünü yurtdışından karşılama yoluna gitmektedir. Bunun sonucu olarak da, bir miktar şeker mısırı ithalatı söz konusudur (Atakul 2011). Dünya'da en büyük şeker mısırı üreticisi ülke $A B D$, en fazla dondurulmuş taze şeker mısırı ihracatı yapan ülke ABD (64 980 ton), en önemli ithalatçı ülke ise Japonya'dır (44 051 ton). Türkiye'de ise, 2008 yılında 4547 ton dondurulmuş şeker mısırı ithalatı yapılmıştır (Anonymous, 2008).

Şeker mısırı, A.B.D.'de kişi başına yılda 3.4 $\mathrm{kg}$ taze koçan, $2.7 \mathrm{~kg}$ konserve ve $0.8 \mathrm{~kg}$ dondurulmuş olmak üzere toplam $6.9 \mathrm{~kg}$ tüketilmektedir (Çetinkol 1989). Çalışmanın amacı; tatı mısır çeşitlerinin, ekim zamanlarının ve hasat dönemlerinin taze tatlı mısırın gıda prosesleri açısından kalite özelliklerinin ortaya konulmasıdır.

\section{Metaryal ve Yöntem}

Araştırmada materyal olarak kullanılan tatı mısırlar (Zea mays saccharata), Ege Üniversitesi Ziraat Fakültesi Tarla Bitkileri Bölümü tarafından sağlanmıştır. Çalışmada El toro, Merkür ve Sunshine olmak üzere üç farklı çeşit tatlı mısır kullanıımıştır. Ekim zamanlarına bakıldığında, ilk ekim 06.05.2011 (1. Dönem), ikinci ekim 20.07.2011 (2. Dönem) ve son olarak üçüncü ekim 20.08.2011 (3. Dönem) olmak üzere üç farklı ekim gerçekleştirilmiştir. Hasatlar süt olum (1. Hasat), sarı olum (2. Hasat) ve hamur olum (3. Hasat) olmak üzere üç farklı zamanlarda gerçekleştirilmiş ve her bir hasat zamanı arasında yaklaşık bir hafta süre bırakılmıştır.

Çalışmada; Tane boyutları, 1000 tane ağırlığı, Toplam kuru madde, Suda çözünür kuru madde (briks), Tekstür, Renk , Şeker, Nişasta ve Protein tayinleri yapılmıştır. Ayrıca, duyusal analizler de gerçekleştirilmiştir.
Çalışmada; tatlı mısırların çeşidi, ekim zamanı ve hasat zamanlarının kalite kriterlerinin üzerine etkisinin belirlenebilmesi için verilere SPSS 16.0 for Windows yazılımında varyans analizi (ANOVA) uygulanmış ve önemli olan farklılıklar için Duncan çoklu testi kullanılarak $\alpha=0.05$ önem düzeyinde incelenmiştir.

\section{Bulgular ve Tartışma}

Üç tatlı mısır çeşidinin ekimden hasada kadar geçirdikleri gün sayısı kıyaslandığında Sunshine çeşidinin olgunlaşması için gerekli olan sürenin bütün ekim zamanlarında diğer çeşitlere göre daha kısa sürdüğü görülmüştür. Sunshine çeşidi diğer çeşitlere göre daha hızlı olgunlaşma hızına sahiptir. Ekimden hasada kadar geçen gün sayısı incelendiğinde 20 Temmuz ekim zamanında üç çeşitte olgunlaşma için daha az güne intiyaç duymuş, 20 Ağustos ekim zamanı incelendiğinde ise üç çeşit için de olgunlaşma süreleri diğer dönemlere göre daha uzun sürmüştür. Ekimden hasada kadar geçen gün sayısındaki bu farklar hava sıcaklığı ve hava neminden etkilenmektedir. Diğer dönemlere göre daha soğuk ve daha nemli geçen 20 Ağustos ekim zamanında çeşitlerin olgunlaşma süresi uzarken, 20 Ağustos'a göre daha sıcak ve daha az nemli geçen 6 Mayıs ve 20 Temmuz ekim zamanlarında çeşitlerin olgunlaşma süreleri kısalmıştır.

Tatı mısırların toplam şeker yönünden çeşit, ekim zamanı, hasat dönemi ve interaksiyonlarının istatistiksel olarak önemli olduğu gözlenmiştir (Çizelge 1). Çizelge 1 incelendiğinde, tatlı mısır çeşidinin, ekim zamanının ve hasat dönemlerinin toplam şeker değerlerini önemli düzeyde etkilediği saptanmıştır $(P<0.05)$. Ayrıca tatı mısır çeşidi, ekim zamanı ve hasat dönemlerinin interaksiyonlarının da toplam şeker değerleri üzerine etkisinin anlamlı olduğu görülmektedir $(P<0.05)$.

Toplam şeker miktarlarının değer aralığı \%6.46-13.60 arasında bulunmuştur (Çizelge 2). Hasat dönemi geciktikçe toplam şeker miktarında düşüşün gözlendiği tespit edilmiştir. Bu sebepten süt olum hasat dönemleri diğer hasat dönemlerine göre daha yüksek toplam şeker değerlerine sahiptirler. Ekim zamanlarına bakıldığında, toplam şeker miktarlarındaki düşüş birinci ve ikinci ekim zamanında hasat dönemleri geciktikçe daha hızlı gerçekleşirken, üçüncü ekim zamanında hava sıcaklığı ve hava 
Çizelge 1. Tatı mısır çeşidi, ekim zamanı ve hasat zamanının toplam şeker değerleri üzerine etkisinin ANOVA tablosu

Table 1. ANOVA table of sweet corn varieties, planting times and harvesting periods with their effects on total sugar contents

\begin{tabular}{llcccc}
\hline \multicolumn{1}{c}{ Kaynak } & Kareler Toplamı & SD & Kareler Ortalaması & F Değeri & p-değeri \\
\hline Model & 420.492 & 26 & $16.173^{* *}$ & 477.432 & 0.000 \\
X $_{1}$ - Çesit & 108.361 & 2 & $54.181^{* *}$ & 1599.451 & 0.000 \\
X $_{2}$ Ekim zamanı & 98.768 & 2 & $49.384^{* *}$ & 1457.854 & 0.000 \\
X3 $_{3}$ Hasat dönemi & 119.524 & 2 & $59.762^{* *}$ & 1764.213 & 0.000 \\
X1X2 & 65.073 & 4 & $16.268^{* *}$ & 480.251 & 0.000 \\
X1X3 & 2.938 & 4 & $0.735^{* *}$ & 21.684 & 0.000 \\
X2X3 & 7.751 & 4 & $1.938^{* *}$ & 57.203 & 0.000 \\
X1X2X3 & 18.077 & 8 & $2.260^{* *}$ & 66.706 & 0.000 \\
Hata & 2.744 & 81 & 0.034 & & \\
Toplam & 423.235 & 107 & & & \\
\hline
\end{tabular}

bağıl nemine bağlı olarak bu düşüş daha yavaş gerçekleşmiştir. Bu sebepten üçüncü ekim zamanındaki toplam şeker miktarları daha iyi sonuçlar vermiştir. Çeşitler arasından Sunshine diğer çeşitlere göre hasat dönemi ilerledikçe daha yavaş toplam şeker kaybı yaşamış ve en iyi toplam şeker sonuçlarını vermiştir. Toplam şekerin duyusal analiz lezzet sonuçlarına direk etkisi olduğu için yüksek miktardaki toplam şeker değerine sahip sonuçlar panelistler tarafından beğenilmiştir. Özellikle Sunshine çeşidinin üçüncü ekim zamanının süt olum hasat döneminde en yüksek değeri alması bu çeşidin tercih edilmesine sebep olacaktır. hasat dönemleri belirlendiğinde; Sunshine çeşidi için 6 Mayıs ekim zamanında süt olum hasat dönemi (ekimden hasada kadar geçen süre 83 gün), 20 Temmuz ekim zamanında süt olum hasat dönemi (ekimden hasada kadar geçen süre 72 gün), 20 Ağustos ekim zamanında süt olum hasat dönemi (ekimden hasada kadar geçen süre 89 gün) olarak belirlenmiştir.

Aynı özelliklere göre optimum hasat dönemleri Merkür çeşidi için 6 Mayıs ekim zamanında süt olum hasat dönemi (ekimden hasada kadar geçen süre 87 gün), 20 Temmuz ekim zamanında süt olum hasat dönemi

Çizelge 2. Tatlı mısır tanelerinin toplam şeker tayini değerleri

Table 2. Total sugar contents of sweet corns

\begin{tabular}{|c|c|c|c|c|c|}
\hline \multirow{3}{*}{$\begin{array}{l}\text { Ekim } \\
\text { Zamanı }\end{array}$} & \multirow{3}{*}{$\begin{array}{l}\text { Hasat } \\
\text { Tarihleri }\end{array}$} & \multirow{3}{*}{$\begin{array}{l}\text { Hasat } \\
\text { Dönemi }\end{array}$} & \multicolumn{3}{|c|}{ Toplam Şeker (\%) } \\
\hline & & & \multicolumn{3}{|c|}{ Çeşit } \\
\hline & & & Sunshine & Merkür & El toro \\
\hline \multirow{4}{*}{ 06.Mayıs } & \multirow{3}{*}{$\begin{array}{l}28 \text { Temmuz } \\
17 \text { Ağustos }\end{array}$} & Süt Olum & $13.04 \pm 0.14 \mathrm{I}$ & $13.34 \pm 0.36^{m}$ & $11.36 \pm 0.26^{J}$ \\
\hline & & Sarı Olum & $11.31 \pm 0.14^{J}$ & $9.85 \pm 0.12^{\dagger}$ & $9.22 \pm 0.07^{\mathrm{e}}$ \\
\hline & & Hamur olum & $9.61 \pm 0.17^{\dagger}$ & $9.63 \pm 0.23^{\dagger}$ & $9.23 \pm 0.23^{\mathrm{e}}$ \\
\hline & \multirow{3}{*}{$\begin{array}{l}30 \text { Eylül - } \\
20 \text { Ekim }\end{array}$} & Süt Olum & $13.31 \pm 0.40^{\mathrm{m}}$ & $7.41 \pm 0.08^{c}$ & $10.50 \pm 0.23^{h}$ \\
\hline \multirow[t]{2}{*}{ 20.Temmuz } & & Sarı Olum & $11.23 \pm 0.10^{\jmath}$ & $7.15 \pm 0.11^{\mathrm{D}}$ & $7.69 \pm 0.13^{a}$ \\
\hline & & Hamur Olum & $10.12 \pm 0.02^{g}$ & $6.46 \pm 0.08^{a}$ & $6.55 \pm 0.15^{\mathrm{a}}$ \\
\hline \multirow{3}{*}{ 20.Ağustos } & \multirow{3}{*}{$\begin{array}{c}17 \text { Kasım - } \\
5 \text { Aralık }\end{array}$} & Süt Olum & $13.60 \pm 0.08^{n}$ & $11.94 \pm 0.13^{\mathrm{K}}$ & $10.81 \pm 0.25^{1}$ \\
\hline & & Sarı Olum & $11.37 \pm 0.10^{\rfloor}$ & $11.45 \pm 0.11^{J}$ & $9.77 \pm 0.16^{\dagger}$ \\
\hline & & Hamur Olum & $11.42 \pm 0.21^{J}$ & $10.54 \pm 0.21^{n}$ & $9.33 \pm 0.16^{\mathrm{e}}$ \\
\hline
\end{tabular}

Tatlı mısırın kalite özelliklerinin sonuçları incelendiğinde, optimum hasat zamanlarının belirlenmesinde özellikle şeker ve nişasta değerlerinin tatlı mısırın kimyasal kompozisyonundaki diğer bileşenlere göre daha önemli kabul edildikleri göze alınarak, invert şeker, toplam şeker, nişasta ve duyusal analizlerden lezzet özelliklerine göre optimum (ekimden hasada kadar geçen süre 77 gün), 20 Ağustos ekim zamanında hamur olum hasat dönemi (ekimden hasada kadar geçen süre 107 gün) olarak belirlenmiştir.

İncelenen özelliklere göre El toro çeşidi için optimum hasat dönemleri 6 Mayıs ekim zamanında süt olum hasat dönemi (ekimden 
hasada kadar geçen süre 89 gün), 20 Temmuz ekim zamanında süt olum hasat dönemi (ekimden hasada kadar geçen süre 79 gün), 20 Ağustos ekim zamanında sarı olum hasat dönemi (ekimden hasada kadar geçen süre 100 gün) olarak belirlenmiştir.

Çeşitlerin kalite özelliklerine bakıldığında, Sunshine çeşidinin toplam şeker, nişasta ve duyusal özelliklerden lezzet ve doku özelliklerine göre en iyi değerlere sahip olduğu anlaşılmaktadır. Merkür çeşidinin ise suda çözünür kuru madde, invert şeker, protein ve duyusal özelliklerden renk özelliğine göre en iyi değerlere sahip olduğu dikkati çekmektedir. Eltoro çeşidinin ise toplam kuru madde ve duyusal özelliklerden görünüş özelliğine göre en iyi değerlere sahip olduğu görülmektedir.

\section{Sonuç}

Sonuç olarak, taze veya işlenmiş olarak kullanılmasının dışında, yılın hangi tarihlerinde ekilip, hangi döneminde hasat edilmesine bağlı olarak tatlı mısır çeşitlerinin şeker oranları değişiklik gösterebilmektedir. Bulunan bütün analiz sonuçları arasında kıyaslama yapıldığında en iyi tatı mısır çeşidinin Sunshine çeşidi olduğu belirlenmiştir.

\section{Kaynaklar}

Anonymous, 1995. AOAC Official methods of Analysis of the Association Agicultural Chemists, ed. Board William Harwitz, Chairman and ed. Commitee on editing methods of analysis. Chichilo, P., Clifford P.A., Reynolds $\mathrm{H}_{\text {., }} 10^{\text {th }}$ ed

Anonymous, 1999. Commission Directive 1999/79/EC

Anonymous, 2008, FAO Statistical Databases. http://faostat.fao.org (Erişim Tarihi: 1 Mayıs 2012)

Anonymous, 2010. FAO Statistical Databases. http://faostat.fao.org (Erişim Tarihi: 1 Mayıs 2012)

Atakul Ş., 2011. Diyarbakır Koşullarında Farklı Ekim Zamanlarının Beş Şeker Mısırı (Zea mays L. saccharata Sturt.) Çeşidinde Taze Koçan ve Tane Verimi İle Bazı Tarımsal Özelliklere Etkisi, Yüksek Lisans Tezi, Çukurova Üniversitesi Fen Bilimleri Enstitüsü, 1-4 s

Çetinkol M., 1989. Tatı Mısır Üretimi. Hasad Aylık Tarım ve Hayvancılık Derg. 4(46): 20-23

Eşiyok D., Bozokalfa M.K. ve Uğur A., 2004, Farklı lokasyonlarda yetiştirilen şeker mısır (Zea mays L. var. sacchrata) çeşitlerinin verim kalite ve teknolojik özelliklerinin belirlenmesi. Ege Üni. Ziraat Fak. Dergisi, 41(1): 1-9 